of vested interests. Yet its duty is to say quite plainly that during the period when modest and tentative initiatives will be made in applying the customer-contractor principle to the research councils, it will institute the careful study of the whole of applied research which is necessary if the fullest use is to be made of the country's scientific power.

\section{Forward by Millimetres}

THE British government is keeping its head low on metrication. The white paper on the subject published last week (see page 297) confirms the previous government's declaration to encourage metrication in Britain and to work to a timetable that will see a large part of the changeover completed by 1975 , but it does so without the enthusiasm with which the old Ministry of Technology embraced the prospect of this change. The reasons, of course, are simple enough. For one thing, the present government's supporters in the House of Commons are lukewarm on the subject. Then the government is having to live uncomfortably with the legacy of decimalization bequeathed to it by $\mathrm{Mr}$ James Callaghan on a system which has brought an unpalatable degree of price inflation in Britain.

No wonder that the government and the Department of Trade and Industry is anxious to keep its head down. No wonder that it accompanies the general advice that metrication is a necessary part of membership of the European Communities with declarations that "it will be a long time" before road signs are changed and that it will be possible for the indefinite future to buy beer and milk by the pint and not the litre. The trouble, of course, is that if metrication is worth having at all, it will need to be encouraged and that this will be possible only if the government makes such a firm commitment to the principle that the Metrication Board can function efficiently.

One of the most obvious gaps in the document now published is its qualitative character. The white paper makes a great deal of the way in which several industries, urged on by the Confederation of British Industry, have voluntarily made the change. In practice, the pharmaceutical industry was understandably one of the first to adopt metric units, but that was a natural development partly because of the international character of its business and partly because British pharmacists were lumbered with a system of weights and measures even more anachronistic than other parts of commercial life. It was something of a surprise that the construction industry in Britain, not conspicuously the most advanced, should have been an early starter, but this is a field in which the standardization of modular sizes has forced the pace. But in the circumstances, it might have been expected that the Department of Trade and Industry could now have had enough experience to spell out in some detail not merely the costs of conversion but also the potential benefits.

The white paper explains that such calculations are complicated by the way in which a decision to convert to metric measures within a factory or an industry is often accompanied by more far-reaching decisions to rationalize a line of products or in which the timing of metrication is chosen so as to fit in with other changes of organization within a company, and it is true that complications like these must necessarily make difficult the calculation of costs. Even so, it would have been helpful to know more about the ways in which the companies which have made the change have found it necessary to lay out money. And what experience has there been on the cost of training people to use unfamiliar units? The fact that it has been hard to quantify experiences like these is, after all, interesting in itself, for it may well be that the difficulties are not nearly as formidable nor as costly as some critics fear they are.

What are the potential benefits? The starting point for objective calculation should be, of course, the experience of those salesmen who are still required by their employers to sell goods abroad in sizes quoted in imperial units. The white paper points out that 15 per cent of the Gross National Product of Britain is at present represented by exports and, although a large part of the export trade is with the United States, there is no question that a large part of the present export business will disappear if metrication is not quickly implemented. And the diversity of the export trade is in itself a proof that the change cannot be confined to a narrow sector of British industry. In the circumstances, it would have been more hopeful if the white paper had contained a more explicit timetable for the change. It should also have had more to say about the ways in which the change could be encouraged in the schools and about the zeal with which it will urge that change on.

\section{Years Ago}

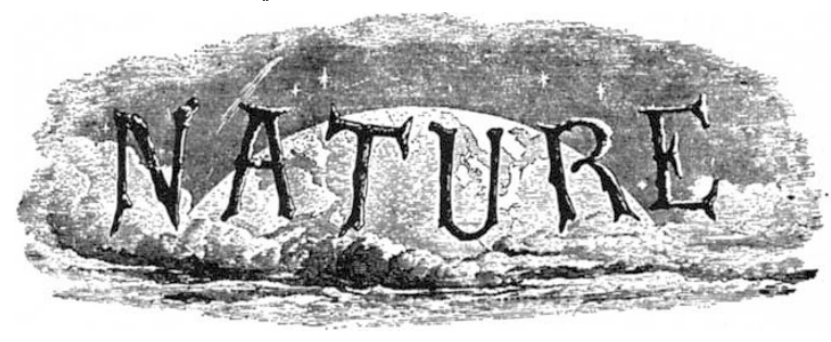

We have reason to know that many weak people have been alarmed, and many still weaker people made positively ill, by an announcement which has appeared in almost all the newspapers, to the effect that Prof. Plantamour, of Geneva, has discovered a comet of immense size, which is to "collide," as our American friends would say, with our planet on the I2th of August next. IVe fear that there is no foundation whatever for the rumour. In the present state of science nothing could be more acceptable than the appearance of a good large comet, and the nearer it comes to us the better, for the spectroscope has a long account to settle with the whole genus, which up to this present time has fairly eluded our grasp. But it is not too much to suppose that the laymen in these matters might imagine that discovery would be too dearly bought by the ruin of our planet. Doubtless, if such ruin were possible, or indeed probable-but let us discuss this point. Kepler, who was wont to say that there are as many comets in the sky as fishes in the ocean, has had his opinion endorsed in later times by Arago, who has estimated the number of these bodies which traverse the solar system as $17,500,000$ But what follows from this? Surely that comets are very harmless bodies or the planetary system, the earth included, would have suffered from them long before this, even if we do not admit that the earth is as old as geulogists would make it.

From Nature, 5, 310, February 15, 1872 